\title{
25 Research Square \\ The Plastic Hinge Length Prediction of RC Members by Using ANN
}

\section{Baris Bayrak}

Ataturk University

\section{Gökhan KAPLAN}

Ataturk University

Oğuzhan Akarsu

Ataturk University

Abdulkadir Cüneyt AYDIN ( $\nabla$ acaydin@atauni.edu.tr)

Ataturk University

\section{Research Article}

Keywords: reinforced concrete, shear wall, column, plastic hinge, ANN

Posted Date: February 16th, 2022

DOI: https://doi.org/10.21203/rs.3.rs-1316743/v1

License: (c) (1) This work is licensed under a Creative Commons Attribution 4.0 International License.

Read Full License 


\title{
The Plastic Hinge Length Prediction of RC Members by Using ANN
}

\author{
Barış BAYRAK, Gökhan KAPLAN, Oğuzhan AKARSU, Abdulkadir Cüneyt AYDIN*,
}

Ataturk University, Engineering Faculty, Department of Civil Engineering, 25030, Erzurum, TURKEY

${ }^{*}$ Corresponding Author: acaydin@atauni.edu.tr

\begin{abstract}
For many years, plastic hinges have been a very interesting and complex topic for researchers and engineers due to plastic deformations. Nonetheless, both standards and empirical relations are insufficient to determine the length of plastic hinges attached to concrete flexural elements. This study aims to analyze studies and formulas used for the calculation of plastic hinges in reinforced concrete (RC) columns and RC sheer walls. In addition, the study also evaluated the effect of plastic hinge behavior on other structural members. The study also evaluated plastic hinge length formulas and plastic hinge formulas of flexure elements either created with numerical modelling or presented with numerical models supported by empirical data. In addition, the data for columns and/or shear walls included in the literature have been evaluated in order to develop a unique formula that anticipates the length of plastic hinges of columns and/or shear walls. In this study, the use of Levenberg-Marquardt Algorithm based on artificial neural network (ANN) models in estimating the plastic hinge length of columns and shear walls was investigated. It was observed that the $\mathrm{R}^{2}$ values of the model outputs are greater than 0.98 . It has been determined that the developed ANN model is a practical and useful method for estimating the plastic hinge length of columns and shear walls, both.
\end{abstract}

Keywords: reinforced concrete, shear wall, column, plastic hinge, ANN

\section{INTRODUCTION}

Plastic hinge flexural is known as the area in which deformation in flexural elements and plastic deformations determining the flexural capacity take place. Once it reaches moment flexural capacity as a result of the increasing load, the plastic hinge becomes unable to bear the moment after a certain while. "Hinge" used in the term "plastic hinge" refers to the classic and stable hinge which is unable to bear a load with momentum. "Plastic" word, on the other hand, means that this hinge bears the increasing weight of the flexural element by displaying plasticity (bending, flexure) feature. Behavior of structural members have great importance especially outside the elastic zone, which is the plastic. Especially in the case of earthquake forces, plastic deformation capacity of its flexural elements are very important for the overall safety of the building. Considering the fact that forces effecting the structure will reveal an energy, this conveyed energy shall be absorbed by the structure. Absorption of this energy could be accomplished by construction elements such as columns, girders and shear walls. In another saying, plastic deformation or plastic rotation features of structural members are vital for a building to endure and absorb the energy, such as earthquakes, that affect the building. Plastic deformations of reinforced concrete members happen in the form of deflections around the plastic hinge and yield of reinforcements $[1,2]$.

Another important concept in RC systems is the redistribution of momentum. If the plastic deformation values of concrete and reinforcement elements are within limits (which means the rotation capacity of the plastic hinge is enough) in case a section reaches its threshold moment flexural capacity, redistribution of external forces shall be valid for this structure system. Among the plastic hinge region, the flexural moment values are relatively small. As a result, the mentioned zone can be thought as behaving linear elastic. Increased moment, causes elastic and plastic deformations. In the frame type structural systems, plastic hinges are located in the intersections of the columns and beams. For the shear walls, they are located at the floor level of each floor (shear base) (Figure 1). As displayed at Figure 1, increasing the level of hyperstaticity in frame systems shall increase the number of plastic hinges. Hence, redistribution of the moment, becomes more effective. For this reason, each floor has to be manufactured monolithically for RC structures [3-6]. 


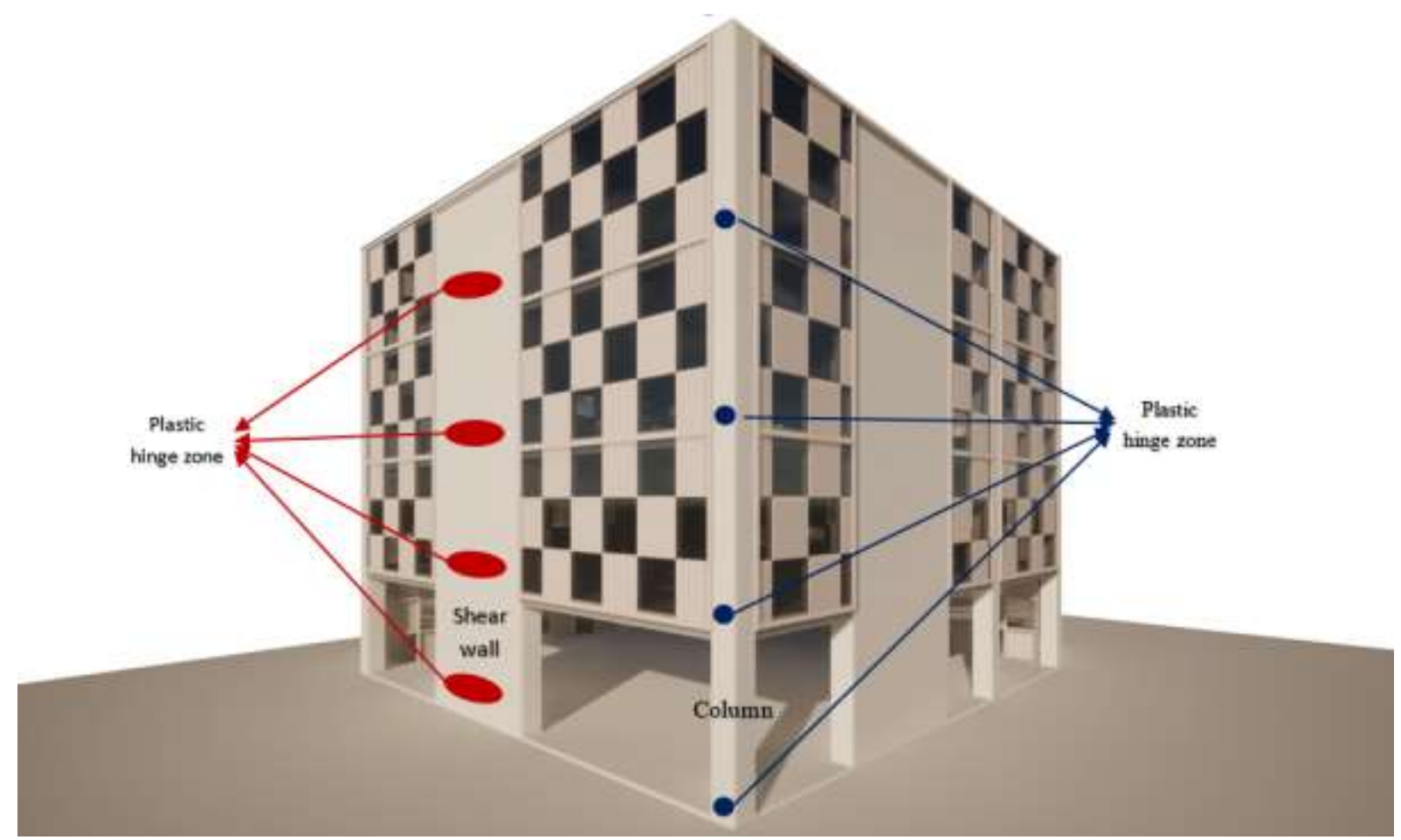

Figure 1. Plastic hinge zone in shear wall and frame systems

Accurately defining the plastic hinge zone is very hard and important, especially in analytical studies. Nonetheless, empirical studies conducted on this subject until now has not been very detailed in terms of defining the length of the plastic hinge zone regardless of its position; columns, beams or shear walls.

Plastic hinge length in flexural members are not defined with a specific formula. Various researchers suggest various formulations for plastic hinge length. The previous explanations present, how hard and important is this zone for structural safety. One of the necessary capacity parameters of the design of columns, beams and shear walls is the fact of plastic hinges [7]. This approach assumes that shape deformations throughout the axis of the structural member is focused on a certain region (plastic hinge zone). In the design process of RC members, small deformations and large translocations are very important factors for accurate behavior of the member. The aim of this study is to evaluate a unique formula by using numeric and/or numerically produced plastic hinge related observations and/or predictions throughout the literature with artificial neural networks for both RC columns and shear walls, which will also demonstrate an innovative application of ANN.

\section{Plastic Hinge Length of RC Columns and Shear Wall}

For the RC columns, plastic hinge zone has a significant effect on column behavior. Total rotation capacity or plastic rotation capacity of the plastic hinge zone is directly associated with column performance. Figure 2 shows a sample image of plastic hinge region art RC columns. 


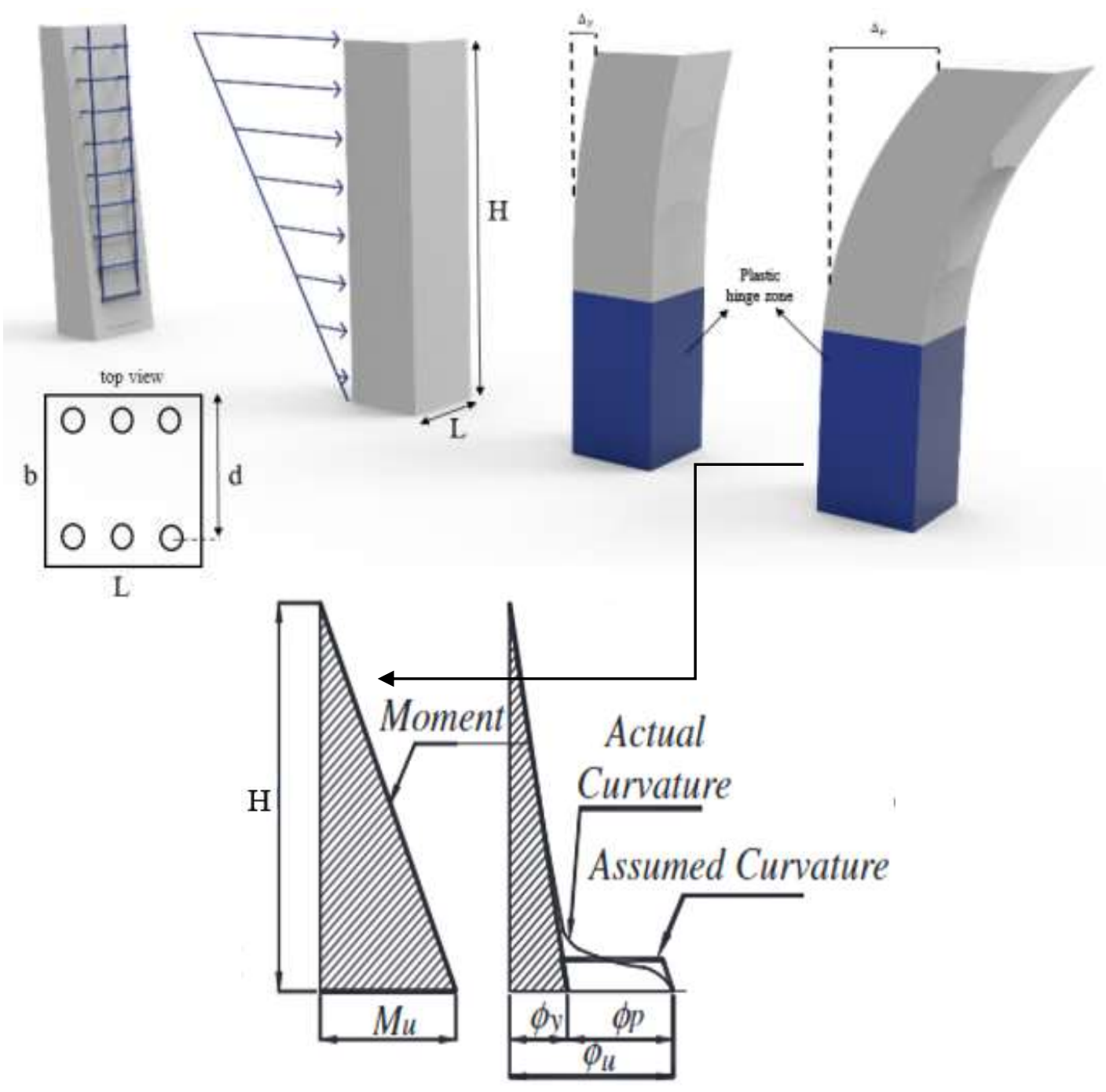

Figure 2. Plastic hinge approach for columns

The ultimate displacement $\left(\Delta_{\mathrm{u}}\right)$ in columns is expressed by Equation 1 .

$$
\begin{gathered}
\Delta_{\mathrm{u}}=\Delta_{\mathrm{y}}+\Delta_{\mathrm{p}}=\frac{\emptyset_{\mathrm{y}} H}{3}+\left(\varnothing_{\mathrm{u}}-\emptyset_{\mathrm{y}}\right) \mathrm{l}_{\mathrm{p}}\left(\mathrm{H}-0,5 \mathrm{l}_{\mathrm{p}}\right) \\
\theta_{\mathrm{u}}=\frac{\Delta_{\mathrm{u}}}{\mathrm{H}}=\frac{\emptyset_{\mathrm{y}} \mathrm{H}^{2}}{3}+\frac{\left(\varnothing_{\mathrm{u}}-\emptyset_{\mathrm{y}}\right) \mathrm{l}_{\mathrm{p}}\left(\mathrm{H}-0,5 \mathrm{l}_{\mathrm{p}}\right)}{\mathrm{H}} \\
\emptyset_{\mathrm{y}}=\lambda \frac{\varepsilon_{\mathrm{Y}}}{\mathrm{D}}
\end{gathered}
$$

For the RC columns at frame type structures, deformation capacity (column performance) has a very important role in the overall design due to the fact that columns are subjected to immense seismic loads. Plastic deformation capacity of the columns might be obtained by using sufficient web reinforcement at the plastic hinge zone.

The determination of the plastic hinge zone by researchers or engineers are very important, especially in terms of seismic design for RC shear walls. Estimation of the plastic length is not only important in terms of design of new members, but also in terms of repair and effective use of existing members[9$11]$.

A plastic hinge model is exhibited at Figure 3 and $\mathrm{H}_{\mathrm{w}}$ and $\mathrm{L}_{\mathrm{w}}$ respectively display shear wall height and the length of the RC shear wall of a rectangular section. As seen at Figure 3, the maximum curvature 
throughout the plastic hinge is equal to the sum of the curvatures at the yielding point and the plastic stage.

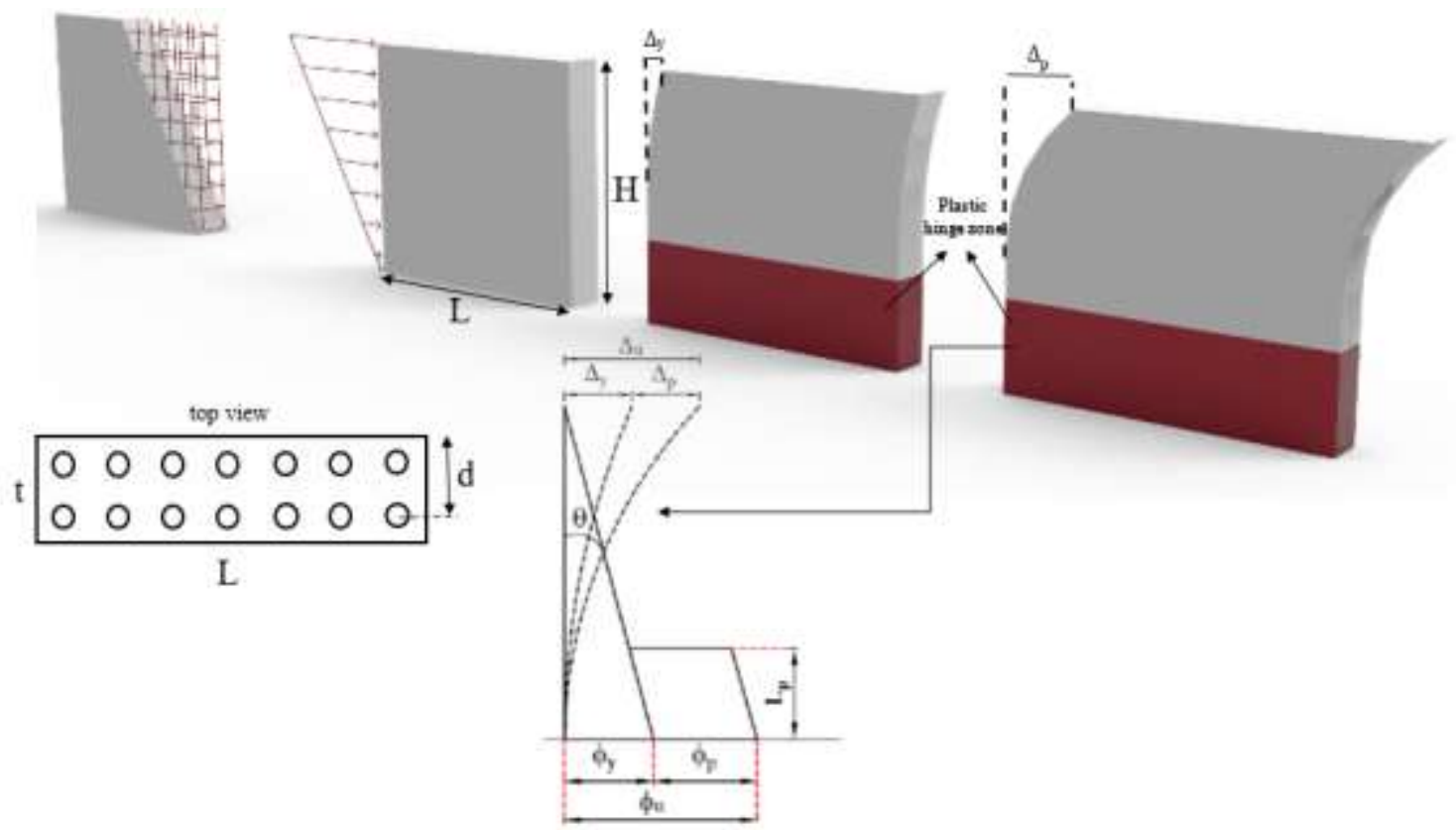

Figure 3. Plastic hinge model in RC shear walls

$$
\begin{gathered}
\theta_{\mathrm{p}}=\emptyset_{\mathrm{p}} \mathrm{L}_{\mathrm{p}}=\left(\emptyset_{\mathrm{u}}-\emptyset_{\mathrm{y}}\right) \mathrm{L}_{\mathrm{p}} \\
\Delta_{\mathrm{y}}=\frac{\emptyset_{\mathrm{y}} \mathrm{H}_{\mathrm{w}}}{3} \\
\Delta_{\mathrm{p}}=\theta_{\mathrm{p}}\left(\mathrm{H}-0,5 \mathrm{~L}_{\mathrm{p}}\right)=\left(\emptyset_{\mathrm{u}}-\emptyset_{\mathrm{y}}\right) \mathrm{L}_{\mathrm{p}}\left(\mathrm{H}-0,5 \mathrm{~L}_{\mathrm{p}}\right) \\
\Delta_{\mathrm{u}}=\Delta_{\mathrm{y}}+\Delta_{\mathrm{p}}=\frac{\emptyset_{\mathrm{y}} \mathrm{H}}{3}+\left(\varnothing_{\mathrm{u}}-\emptyset_{\mathrm{y}}\right) \mathrm{L}_{\mathrm{p}}\left(\mathrm{H}-0,5 \mathrm{~L}_{\mathrm{p}}\right)
\end{gathered}
$$

The length of the plastic hinge zone is directly correlated to shear wall height or drift ratio for RC shear wall. Plastic hinge zones that are formed at the shear base are very important in terms of shear wall behavior. The shear wall behavior is mainly affected with the energy absorption capacity, the plastic deformation capability, and the rotation capacity. For the squat shear walls $(\mathrm{H} / \mathrm{L}<2)$ plastic hinge length $\mathrm{L}_{\mathrm{w}}$ and shear length are observed as $\mathrm{L}_{\mathrm{p}}=\mathrm{L}_{\mathrm{w}} / 2$. The displacements are non-linearly distributed throughout the shear walls, while concentrating at the base. The formulas based on the empirical and/or numerical studies or widely used standards for RC columns and/or shear walls are presented at Table 1 and the parameters that affect the plastic hinge length are given at Table 2. Both, for columns and shear walls, there are no specific formulas for the calculation of plastic hinge length, neither at the mentioned standards; nor at the literature. 
Table 1. Plastic hinge length formulas of RC columns and RC shear walls

\begin{tabular}{|c|c|c|}
\hline Standard/Researcher/Model & Plastic Hinge Length $\left(L_{p}\right)$ Formulas & Member \\
\hline Chinese Standard (2008) [8] & $(2 / 3) b \quad$ and $\quad 0,08 L+0,022 d_{s} f_{y} \geq 0,44 d_{s} f_{y}$ & \multirow{9}{*}{$\frac{\Xi}{3}$} \\
\hline AASHTO-8 (2002) [12] & $0,08 \mathrm{H}+0,9 \mathrm{~d}_{\mathrm{s}}$ & \\
\hline Eurocode-8 (2005) [13] & $0,1 \mathrm{H}+0,015 \mathrm{~d}_{\mathrm{s}} \mathrm{f}_{\mathrm{y}}$ and $(0,4 \sim 0,6) \mathrm{L}$ & \\
\hline Japan Standard (1996) [14] & $0,2 \mathrm{H}-0,1 \mathrm{~L}$ and $0,1 \mathrm{~L} \leq \mathrm{L}_{\mathrm{p}} \leq 0,5 \mathrm{~L}$ & \\
\hline Baker $^{*}(1956)[15]$ & $\mathrm{k}_{1} \mathrm{k}_{2} \mathrm{k}_{3}\left(\frac{\mathrm{z}}{\mathrm{d}}\right)^{0,25} \mathrm{~d}$ & \\
\hline Priestley and Park (1987) [16] & $0,08 \mathrm{H}+6 \mathrm{~d}_{\mathrm{s}}$ & \\
\hline Paulay and Priestley (1992) [17] & $0,08 \mathrm{H}+0,022 \mathrm{f}_{\mathrm{y}} \mathrm{d}_{\mathrm{s}}$ & \\
\hline Bae and Bayrak (2008) [18] & $\begin{array}{c}{\left[\left(0,3\left(\mathrm{P} / \mathrm{P}_{\mathrm{o}}\right)+3\left(\mathrm{~A}_{\mathrm{s}} / \mathrm{A}_{\mathrm{g}}\right)-0,1\right)((\mathrm{H} / \mathrm{L}))+0,25\right] \mathrm{H}} \\
\geq 0,25 \mathrm{~L}\end{array}$ & \\
\hline Berry et al. (2008) [19] & $0,05 \mathrm{~L}+0,1 \mathrm{f}_{\mathrm{y}} \mathrm{d}_{\mathrm{s}} / \sqrt{\mathrm{f}_{\mathrm{c}}}$ & \\
\hline Turkey Standard (2019) [20] & $0,5 \mathrm{~L}$ & \multirow{10}{*}{ 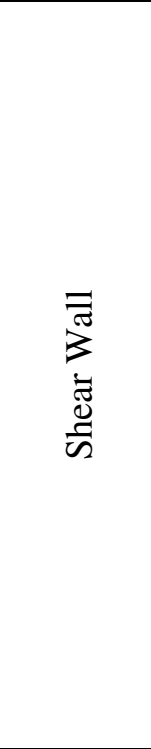 } \\
\hline ACI CODE-318-19 (2019) [21] & $0,4 \mathrm{~L}+0,1 \mathrm{H}$ & \\
\hline Eurocode-8 (2005) [13] & $\frac{\mathrm{L}_{\mathrm{v}}}{30}+0,2 \mathrm{~L}_{\mathrm{w}}+0,11 \frac{\mathrm{d}_{\mathrm{s}} \mathrm{f}_{\mathrm{y}}}{\sqrt{\mathrm{f}_{\mathrm{c}}}}$ & \\
\hline Altheeb et al. (2015) [22] & $\frac{\left(f_{u}-f_{y}\right) d_{s}^{1,2}}{4 \sqrt{f_{c}}}$ & \\
\hline Bohl and Adebar (2011) [23] & $\left(0,2 \mathrm{~L}_{\mathrm{w}}+0,05 \mathrm{H}\right)\left(1-1,5 \frac{\mathrm{P}}{\mathrm{Ag}_{\mathrm{g}}}\right) \leq 0,8 \mathrm{~L}$ & \\
\hline Calvi et al (2007) [24] & $\min \left(0,2\left(\frac{f_{u}}{f_{y}}-1\right) ; 0,08\right) z+0,2 L_{w}+0,022 f_{y} d_{s}$ & \\
\hline Thomsen and Wallace (2004) [25] & $0,33 \mathrm{~L}$ & \\
\hline Priestley and Mattock (2019) [26] & $0,08 \mathrm{~L}+0,022 \mathrm{f}_{\mathrm{y}} \mathrm{d}_{\mathrm{s}}$ & \\
\hline Paulay and Priestley (1992) [17] & $0,2 \mathrm{~L}+0,07\left(\frac{\mathrm{M}}{\mathrm{V}}\right)$ & \\
\hline Park ve Paulay (1990) [27] & $0,5 \mathrm{~L}$ & \\
\hline Proposed model & $\begin{array}{r}0,07 \mathrm{H}-0,01 \mathrm{~L}+0,08 \mathrm{t}-0,21 \mathrm{f}_{\mathrm{c}}+0,18 \mathrm{f}_{\mathrm{y}}+0,1 \mathrm{f}_{\mathrm{u}}+6,4 \rho \\
-0,03 V+\left(\frac{M}{50000}\right)+6,6 d-100\end{array}$ & $\begin{array}{l}\text { Column } \\
\text { and } \\
\text { Shear } \\
\text { Wall }\end{array}$ \\
\hline
\end{tabular}

Withal, Table 1 includes formulas developed in this study both for RC columns and shear walls. The moment related parameters such as width (the length of shear wall in vertical direction of thickness of the wall, but not the dimension vertical to the ground), shear span (the distance between shear force to the shear wall and the ground), effective height (d), and deformation parameters such as reinforcement yield strength, longitudinal reinforcement diameter, reinforcement ratio and concrete compressive strength have been taken into consideration for the formulas that have been used to calculate plastic hinge length of column and shear wall elements. Generally, axial load level which has a significant effect on column and shear wall behavior has not been used in plastic hinge formulas. While axial load level increases plastic hinge length in reinforced concrete columns, it reduces the plastic hinge length of shear walls. This plastic hinge length reduction in axially loaded shear walls is a result of decreasing gap between the bending moment at yielding point and the bending moment capacity. 
Table 2. Parameters considered in the formula of plastic hinge length of RC columns and RC shear wall

\begin{tabular}{|c|c|c|c|c|c|c|c|c|c|c|c|c|c|c|c|c|c|}
\hline Standard/Researcher/Model & b & $\mathbf{L}$ & $\mathbf{H}$ & $\mathbf{L}_{\mathbf{v}}$ & $\mathbf{d}_{\mathrm{s}}$ & $\mathbf{f}_{\mathbf{y}}$ & $\mathbf{f}_{\mathbf{c}}$ & $\mathbf{f}_{\mathbf{u}}$ & $\mathbf{z}$ & d & $\mathbf{P}$ & $\mathbf{A}_{\mathbf{s}}$ & $\mathbf{A}_{\mathrm{g}}$ & $\mathbf{M}$ & $\mathbf{V}$ & $\mathbf{t}$ & $\rho$ \\
\hline Chinese Standard (2008) & + & + & - & - & + & + & - & - & - & - & - & - & - & - & - & - & - \\
\hline AASHTO-8 (2002) & - & + & - & - & + & - & - & - & - & - & - & - & - & - & - & - & - \\
\hline Eurocode- 8 (2005)* & - & + & + & - & + & + & - & - & - & - & - & - & - & - & - & - & - \\
\hline Eurocode-8 $(2005)^{* *}$ & - & + & - & + & + & + & + & - & - & - & - & - & - & - & - & - & - \\
\hline Japan Standard & - & + & + & - & - & - & - & - & - & - & - & - & - & - & - & - & - \\
\hline ACI & - & + & + & - & - & - & - & - & - & - & - & - & - & - & - & - & - \\
\hline Turkish Standard & - & + & - & - & - & - & - & - & - & - & - & - & - & - & - & - & - \\
\hline Baker (1956) & - & - & - & - & - & - & + & - & + & + & + & - & - & - & - & - & - \\
\hline Priestley and Park (1987) & - & + & - & - & + & - & - & - & - & - & - & - & - & - & - & - & - \\
\hline Park and Paulay (1990) & - & + & - & - & - & - & - & - & - & - & - & - & - & - & - & - & - \\
\hline Paulay and Priestley (1992)* & - & + & - & - & + & + & - & - & - & - & - & - & - & - & - & - & - \\
\hline Paulay and Priestley $(1992)^{* *}$ & - & + & - & - & - & - & - & - & - & - & - & - & - & + & + & - & - \\
\hline Thomson and Wallece (2004) & - & + & - & - & - & - & - & - & - & - & - & - & - & - & - & - & - \\
\hline Calvi et al. (2007) & - & + & - & - & + & + & - & + & + & - & - & - & - & - & - & - & - \\
\hline Bae and Bayrak (2008) & - & + & + & - & - & - & - & - & - & - & + & + & + & - & - & - & - \\
\hline Berry et al. (2008) & - & + & - & - & + & + & + & - & - & - & - & - & - & - & - & - & - \\
\hline Bohl and Adebar (2011) & - & + & + & - & - & - & + & - & - & - & + & - & + & - & - & - & - \\
\hline Altheed et al. (2015) & - & - & - & - & + & + & + & + & - & - & - & - & - & - & - & - & - \\
\hline Priestley and Mattock (2019) & - & + & - & - & + & + & - & - & - & - & - & - & - & - & - & - & - \\
\hline Proposed model & - & + & + & + & - & + & + & + & - & + & - & - & - & + & + & + & + \\
\hline
\end{tabular}

*the plastic hinge formula of column

** the plastic hinge formula of shear wall

An overview of the parameters used in the formulas suggested by relevant standards and by some researchers for the calculation of plastic hinge length in RC shear walls are presented at Table 2 . The parameters defined for plastic hinge length are generally suggested for rectangular shear wall sections. No separate formulas are provided for shear walls with T, $\mathrm{U}$ or $\mathrm{L}$ sections. An interesting fact is that the multiplier of $\mathrm{L}_{\mathrm{w}}$ is higher than the multiplier of $\mathrm{H}_{\mathrm{w}}$ in formulas in which parameters such as shear wall length $\left(\mathrm{L}_{\mathrm{w}}\right)$ and shear wall height $\left(\mathrm{H}_{\mathrm{w}}\right)$ are used to determine plastic hinge length. This indicates that the shear length is more vital than shear width in terms of determining plastic hinge length in RC shear walls. Nonetheless, calculated plastic hinge length is taken into consideration from the shear base throughout the $\mathrm{H}_{\mathrm{w}}$ height. Plastic hinge area which directly affects shear wall behavior is directly affected by the length of the shear wall. Aspect ratio $\left(\mathrm{H}_{\mathrm{w}} / \mathrm{L}_{\mathrm{w}}\right)$ of $\mathrm{RC}$ shear wall being at least five or six, indicated in respective regulations, is a result of plastic hinge length. Withal, the Turkish and American standards only take into consideration the shear geometry, the European Standard considers concrete and reinforcement characteristics with the shear geometry. The axial load, which has an effect on shear behavior, is generally not included in the calculations. This is mostly due to the endurance increasing effect of axial load level on the shear wall. Therewithal, an increment in the axial load level of columns increases the plastic hinge length whereas the exact opposite is valid for shear walls. Both, in terms of concrete cross-section area and in terms of reinforcement layout, $\mathrm{RC}$ shear walls are very different from 
columns and beams. Hence, plastic hinge length formulas developed for columns shall not be applicable for shear walls in standard ways.

Plastic hinge formulas developed for RC shear walls attribute more importance to shear width in terms of calculation. This is mostly due to the fact that a broadened shear width means higher tensile stress, which results with higher moment of flexure. In addition, diagonal cracks have an effect on plastic hinge length for RC shear walls.

Plastic hinge length of reinforced flexural members varies based on material related or geometrical parameters. However, there is no specific formula in the literature to define plastic hinge length. Formulas vary based on the developing researcher and this is due to its dependence on the characteristic features of RC, behavior of which is almost unforeseeable. Also, the section geometry and other factors might vary accordingly and these are the prominent reasons of this ambiguity. In the moment-flexure relation, flexure in the base of the flexural member, becomes a complex issue once deformations on the maximum moment section take place and the generally used pre-assumption of "plane sections remain plain" makes it more difficult to calculate plastic hinge length.

As a result of the nature of cracks, their location and formation could never be estimated beforehand. However, rough estimations can be made based on parameters such as load type and material properties etc. This is another factor that aggravates the estimation of plastic hinge length. Another factor that aggravates the estimation of plastic hinge length is the fact that it is distributed on an area rather than a limited, precise location. Because, estimating the behavior of elements such as concrete in a specific area is difficult and complex. Another factor is the fact that plastic length is affected by the load type. Also, exposure of structural members to loads such as axial load, moment of flexure, shear force and torsional moment, either separately or altogether (combination of more than one loads) makes this problem a much more complicated one [28].

\section{MATERIAL AND METHOD}

\section{Artifical Neural Network (ANN)}

Artificial neural networks (ANN) is based on the principles of the biological neural system however it ignores and neglects majority of biological features. (ANN) is a network that tries to imitate the structure of brain [29]. A human brain includes 1011 neurons that work in perfect harmony to accomplish a task. ANN is designed to execute a task during the learning phase. Neural networks are composed of layers and smart neurons. The purpose of these neurons is to maintain the relation between inputs and outputs by using mathematical equations. In case the relation between inputs and outputs is irregular, neural network is able to detect whether the relation is linear or non-linear. A prominent ANN model, the Multilayer ANN is used to solve complex problems that cannot be solved by a single layer ANN. The model has the ability to transform non-linear separable objects into linear and separable elements. As displayed in Figure 4, multi-layer ANN is composed of an input layer, output layer and other hidden layers. Output of each layer is the input of the next layer in multi-layer ANN systems. Each layer has its own weight matrix (Figure 4). These weight matrices are modified in order to obtain minimum error level.

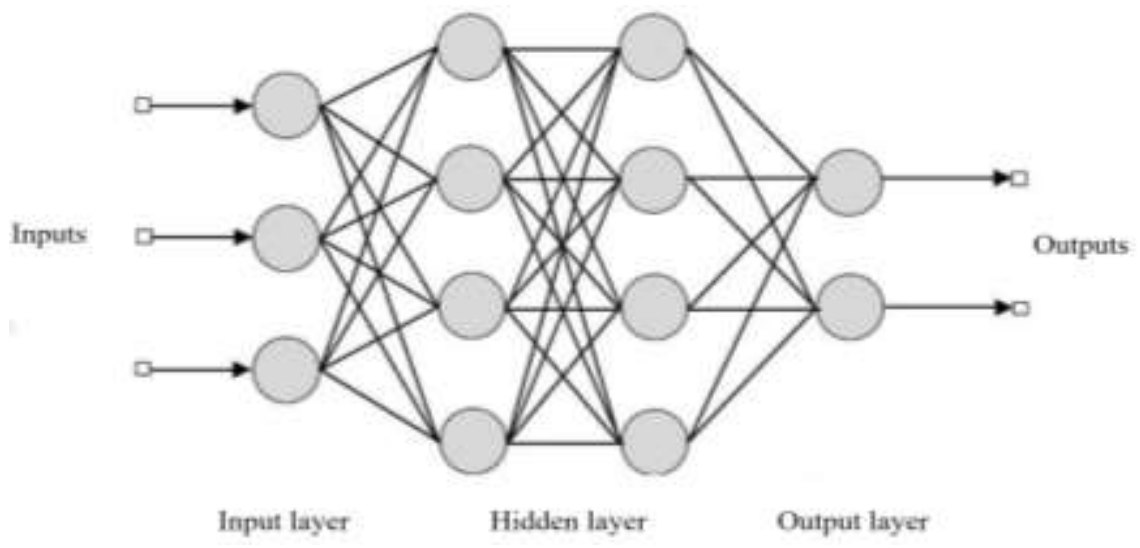

Figure 4. Multi-layer ANN model 
The most important advantage of multi-layer ANN is the ability to work with scarce information. After ANN training, the system might produce output information even with missing data and has the computing ability to conduct multiple transactions simultaneously. Corruption of one or more ANN cells does not prevent the system from producing outputs [30]. Formulas used in multi-layer ANN models are provided as follows:

$$
\begin{gathered}
\mathrm{a}^{1}=f^{1}\left(I W^{1.1} X+B^{1}\right) \\
\mathrm{a}^{2}=f^{2}\left(I W^{2.1} a^{1}+b^{2}\right) \\
\mathrm{a}^{2}=f^{2}\left(I W^{3.2} a^{2}+b^{3}\right) \\
\mathrm{a}^{3}=f^{3}\left(L W 3.2 f^{2}\left(I W^{2.1} f^{1}\left(I W^{1.1} X+b^{1}\right)+b^{2}\right)+b^{3}\right)
\end{gathered}
$$

$\mathrm{X}$ - input vector, IW - input weight matrix, LW - hidden weight matrix, $a$ - deviation vector, $\mathrm{b}$ - layer output vector.

\section{The Levenberg-Marquardt Algorithm}

In order to solve least squares problems, LM algorithm is generally used as a standard algorithm. This algorithm is developed by Levenberg (1944) and Marquardt (1963). Parameter updating transaction of LM algorithm is derivated from steepest descent and Newton algorithms [31]. Different from Newton algorithm, Levenberg-Marquardt algorithm uses an approximate value of a complicated matrix called Hessian matrix $(\mathrm{H}(\mathrm{w}))$ [32]. This solution can be obtained with the Equation 12 [33].

$$
\mathrm{H}(\mathrm{w})=\mathrm{J}^{\mathrm{T}}(\mathrm{w}) \mathrm{J}(\mathrm{w})+\mu \mathrm{I}
$$

Equation 12; $\mu$ stands for Marquardt parameter and I stand for unit matrix. J matrix used in here is also called the Jacobian matrix and is obtained by calculating the first derivatives of network errors based on weighted averages. In the back-propagation of network errors, initially transpose of the Jacobian matrix is used and then network errors are used to calculate the gradient of the network (Equation 13).

$$
\nabla \mathrm{E}(\mathrm{w})=\mathrm{JT}(\mathrm{w}) \text { e }(\mathrm{w})
$$

Once the gradient of the network is calculated, vectoral change of the network weight is calculated by multiplying the adverse Hessian matrix with network gradient (Equation 14) and network weights are updated as displayed in Equation 15.

$$
\begin{gathered}
\Delta \mathrm{w}=-[\mathrm{H}(\mathrm{w})]-1 \nabla \mathrm{E}(\mathrm{w}) \\
\mathrm{W}_{\text {new }}=\text { wold }+\Delta \mathrm{w}
\end{gathered}
$$

LM allorhythmia uses error vector and Jacobian matrix for parameter updating transactions of all sample input values. Jacobian matrix is provided below: [31].

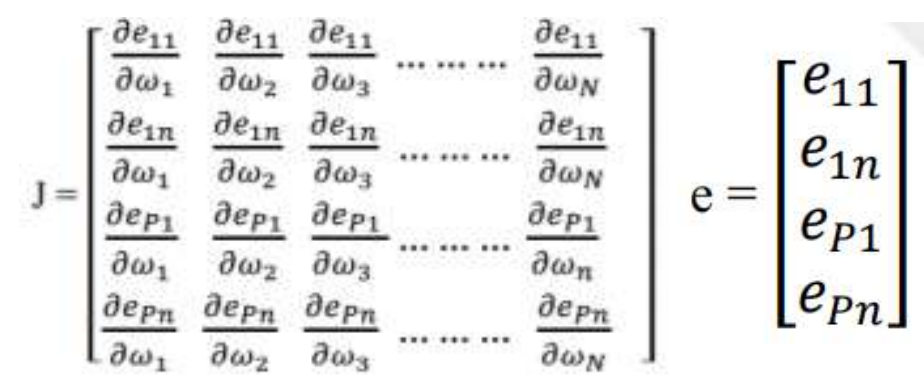

The most important parameter of Levenberg-Marquardt algorithm is " $\mu$ " and it is defined as a scaler number. If $\mu$ converges to zero, the method processes like the Newton algorithm; however when $\mu$ corresponds to a large number, the method transforms into an incrementalist gradient reduction model [34]. 


\section{Application and Results}

In this study, in order to estimate plastic hinge lengths of vertical flexural elements such as columns and shear walls, an ANN model has been developed. In this context, previous studies in the literature has been used. These data consist of 51 shear walls and 227 columns. Sample calculations used in the model are displayed in Table 3.

Table 3. Literature studies used in the ANN model

\begin{tabular}{|c|c|c|c|}
\hline No & References & $\begin{array}{c}\text { Shear } \\
\text { wall }\end{array}$ & Column \\
\hline 1 & Barda et al. (1977) [35] & 7 & - \\
\hline 2 & Synge (1980) [36] & 1 & - \\
\hline 3 & Oesterle et al (1984) [37] & 5 & - \\
\hline 4 & Sato et al (1989) [38] & 22 & - \\
\hline 5 & Lefas et al (1990) [39] & 12 & - \\
\hline 6 & Palermo and Vecchio (2002) [40] & 2 & - \\
\hline 7 & Ma and Li (2018) [41] & 2 & - \\
\hline 8 & Gill et al (1979) [42] & - & 4 \\
\hline 9 & Soesianawati et al (1986) [43] & - & 4 \\
\hline 10 & Zahn et al (1986) [44] & - & 2 \\
\hline 11 & Watson and Park (1989) [45] & - & 5 \\
\hline 12 & Tanaka and Park (1990) [46] & - & 8 \\
\hline 13 & Park and Paulay (1990) [27] & - & 1 \\
\hline 14 & Nagasaka (1982) [47] & - & 2 \\
\hline 15 & Ohno and Nishioka (1984) [48] & - & 3 \\
\hline 16 & Ohue et al. (1985) [49] & - & 2 \\
\hline 17 & Zhou et al (1985) & - & 3 \\
\hline 18 & Zhou et al. (1987) & - & 9 \\
\hline 19 & Kanda et al (1988) [50] & - & 6 \\
\hline 20 & Muguruma et al (1989) [51] & - & 8 \\
\hline 21 & Sakai et (1990) [52] & - & 7 \\
\hline 22 & Wight and Sozen (1973) [53] & - & 14 \\
\hline 23 & Atalay and Penzien (1975) [54] & - & 10 \\
\hline 24 & Saatcioglu and Ozcebe (1989) [55] & - & 4 \\
\hline 25 & Galeota et al (1996) [56] & - & 24 \\
\hline 26 & Wehbe et al (1998) [57] & - & 4 \\
\hline 27 & Lynn et al (1998) [58] & - & 8 \\
\hline 28 & Xiao and Martirossyan (1998) [59] & - & 6 \\
\hline 29 & Sugano (1996) [60] & - & 5 \\
\hline 30 & Bayrak and Sheikh (1996) [61] & - & 8 \\
\hline 31 & Saatcioglu and Grira (1999) [62] & - & 10 \\
\hline 32 & Matamoros et al (1999) [63] & - & 12 \\
\hline 33 & Mo and Wang (2000) [64] & - & 9 \\
\hline 34 & Aboutaha and Machado (1999) [65] & - & 3 \\
\hline 35 & Thomsen and Wallace (1994) [66] & - & 11 \\
\hline 36 & Sezen and Moehle (2002) [67] & - & 3 \\
\hline 37 & Paultre and Legeron (2000) [68] & - & 6 \\
\hline 38 & Paultre et al (2001) [69] & - & 6 \\
\hline 39 & Pujol (2002) [70] & - & 14 \\
\hline \multirow[t]{2}{*}{40} & Takemura and Kawashima (1997) [71] & - & 6 \\
\hline & Total & 51 & 227 \\
\hline
\end{tabular}




\section{RESULTS}

\section{Development of ANN Model}

Determining features such as concealed gradient number, learning pace and beginning weight are relatively hard when using an ANN. Determination of the architecture of a neural network for the solution of a specific problem is an important issue. Because, the topology of the neural network affects all results. Optimum network geometry is obtained by using trial and error method. ANN model is conducted using MATLAB R2015 (a). In this study, ANN model has been selected in the form of neural network with feedforwarding and back-propagation. Learning algorithm of the model uses LevenbergMarquardt. In addition, in the ANN design a single layer consisting of 12 neurons has been used. The network includes ten input parameters. Architectural design of the ANN is provided in Table 4.

Table 4. Structure of ANN

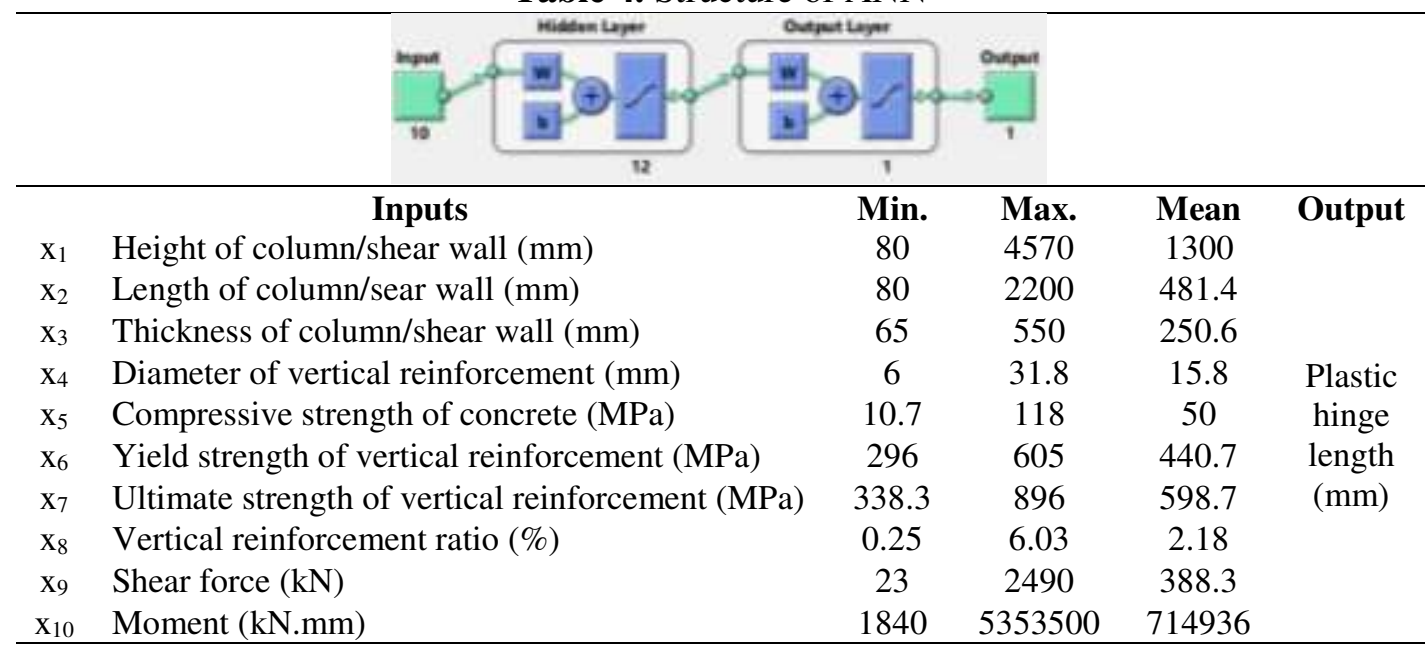

TANSIG has been used for the activation function of the developed network model. Summary of the ANN model has been provided in Table 5.

Table 5. Structure and summary of the ANN model

\begin{tabular}{|c|c|c|}
\hline Properties & Values & Description \\
\hline Dataset & $\begin{array}{l}\text { (Group 1: Shear Wall-51) } \\
\text { (Group 2: Column-227) }\end{array}$ & $\begin{array}{c}18.3 \% \text { of the data are shear walls, } 81.7 \% \\
\text { are columns. }\end{array}$ \\
\hline Inputs & 10 units $\left(\mathrm{x}_{1}, \mathrm{x}_{2}, \ldots \ldots, \mathrm{x}_{10}\right)$ & $\begin{array}{l}\text { Features such as geometry, reinforcement, } \\
\text { concrete compressive strength, shear force } \\
\text { and moment of the carrier system } \\
\text { constitute the input parameters. }\end{array}$ \\
\hline Activation function & $\tan \operatorname{sig}(x)$ & $\operatorname{tansig}(x)=\frac{2}{(1+|-2 x|}-1$ \\
\hline Performance function & MSE & $M S E=\frac{\sum_{i=1}^{n}(\text { predictedoutput }- \text { actualoutput })^{2}}{}$ \\
\hline & & $\begin{array}{c}n \\
\text { Where } \mathrm{n} \text { is the input patterns }\end{array}$ \\
\hline \multirow{5}{*}{ Training parameters } & 0.01 & Learning rate \\
\hline & Levenberg-Marquardt & Learning algorithm \\
\hline & 1000 & epochs \\
\hline & $10^{-7}$ & Performance goal \\
\hline & 12 & Number of neurons \\
\hline
\end{tabular}

\section{Training of the Network}

Once the network architecture is established, then the network has been trained for learning in order to map the relation between inputs and the output (plastic hinge length). $70 \%$ of the data used for the model has been used for training purposes. Out of the remaining data, $15 \%$ has been used for validation and 
$15 \%$ has been used for testing the data. As a result of the training process, plastic hinge length has been calculated with very high $\mathrm{R}^{2}$ values (>0.98). MSE values has also been calculated for 1000 training terms conducted for the models. Other parameters for the training of the network has been provided in Table 5. As a result of the training, plastic hinge lengths calculated with 19 different models have been determined. Methods used for determining plastic hinge lengths used as an output of ANN has been provided in Table 6. $\mathrm{R}^{2}$ values of the training data of 19 different ANN models developed are provided in Figure 5.

Table 6. Plastic hinge lengths estimated as output in ANN model

\begin{tabular}{|c|c|c|c|}
\hline No & References & Formula $\left(\mathrm{L}_{\mathrm{p}}\right)$ & $\begin{array}{c}\text { Structural } \\
\text { member }\end{array}$ \\
\hline 1 & Turkey Standard (2019) & $0,5 \mathrm{~L}_{\mathrm{w}}$ & Shear wall \\
\hline 2 & American Standard (2019) & $0,4 \mathrm{~L}_{\mathrm{w}}+0,1 \mathrm{H}_{\mathrm{w}}$ & Shear wall \\
\hline 3 & \multirow{2}{*}{ China Standard ${ }^{2}$ (2008) } & $(2 / 3) b$ & Column \\
\hline 4 & & $0,08 \mathrm{~L}+0,022 \mathrm{~d}_{\mathrm{s}} \mathrm{f}_{\mathrm{y}}$ & Column \\
\hline 5 & AASHTO (2002) & $0,08 \mathrm{~L}+0,9 \mathrm{~d}_{\mathrm{s}}$ & Column \\
\hline 6 & \multirow{3}{*}{ Eurocode- $8^{1,2,3}(2005)$} & $0,1 \mathrm{~L}+0,015 \mathrm{~d}_{\mathrm{s}} \mathrm{f}_{\mathrm{y}}$ & Column \\
\hline 7 & & $(0,4 \sim 0,6) \mathrm{H}$ & Column \\
\hline 8 & & $\mathrm{~L}_{\mathrm{v}} / 30+0,2 \mathrm{~L}_{\mathrm{w}}+0,11\left(\mathrm{~d}_{\mathrm{bL}} \mathrm{f}_{\mathrm{y}}\right) / \sqrt{ }\left(\mathrm{f}_{\mathrm{c}}\right)$ & Shear wall \\
\hline 9 & Japan Standard (1996) & $0,2 \mathrm{~L}-0,1 \mathrm{H}$ & Column \\
\hline 10 & $\begin{array}{l}\text { Thomsen and Wallece } \\
\text { (2004) }\end{array}$ & $0,33 \mathrm{~L}_{\mathrm{w}}$ & Shear wall \\
\hline 11 & Park and Paulay (1990) & $0,5 \mathrm{~L}_{\mathrm{w}}$ & Shear wall \\
\hline 12 & Paulay and Priestley (1992) & $0,2 \mathrm{~L}_{\mathrm{w}}+0,07(\mathrm{M} / \mathrm{V})$ & Shear wall \\
\hline 13 & Priestley and Park (1987) & $0,08 \mathrm{~L}+6 \mathrm{~d}_{\mathrm{p}}$ & Column \\
\hline 14 & Paulay and Priestley (1992) & $0,08 \mathrm{~L}+0,022 \mathrm{f}_{\mathrm{y}} \mathrm{d}_{\mathrm{b}}$ & Column \\
\hline 15 & Berry (2008) & $0,05 \mathrm{~L}+0,1 \mathrm{f}_{\mathrm{y}} \mathrm{d}_{\mathrm{b}} / \sqrt{ }\left(\mathrm{f}_{\mathrm{c}}\right)$ & Column \\
\hline 16 & $\begin{array}{l}\text { Priestley and Mattock } \\
\text { (2019) }\end{array}$ & $0,08 \mathrm{~L}_{\mathrm{w}}+0,022 \mathrm{f}_{\mathrm{y}} \mathrm{d}_{\mathrm{l}}$ & Shear wall \\
\hline 17 & Altheeb (2015) & $\left(\left(\mathrm{f}_{\mathrm{u}}-\mathrm{f}_{\mathrm{y}}\right) \mathrm{d}_{\mathrm{l}}^{\wedge 1,2}\right) /\left(4 \sqrt{ }\left(\mathrm{f}_{\mathrm{c}}\right)\right)$ & Shear wall \\
\hline 18 & Bohl and Adebar (2011) & $\left(0,2 \mathrm{~L}_{\mathrm{w}}+0,05 \mathrm{H}_{\mathrm{w}}\right)\left(1-1,5 \mathrm{P} /\left(\mathrm{A}_{\mathrm{w}} \mathrm{f}_{\mathrm{c}}\right)\right)$ & Shear wall \\
\hline 19 & Calvi et al.(2007) & $\min \left(0,2\left(f_{u} / f_{y}-1\right) ; 0,08\right) L_{s}+0,2 L_{w}+0,022 f_{y} d_{l}$ & Shear wall \\
\hline
\end{tabular}

As presented at Figure 5, the $\mathrm{R}^{2}$ values of training data vary between 0.98 and 1.00. It is apparent that the L-M algorithm of the used model provided to be very useful for the training. $\mathrm{R}^{2}$ values of the test data of the model are shown at the Figure 6. 


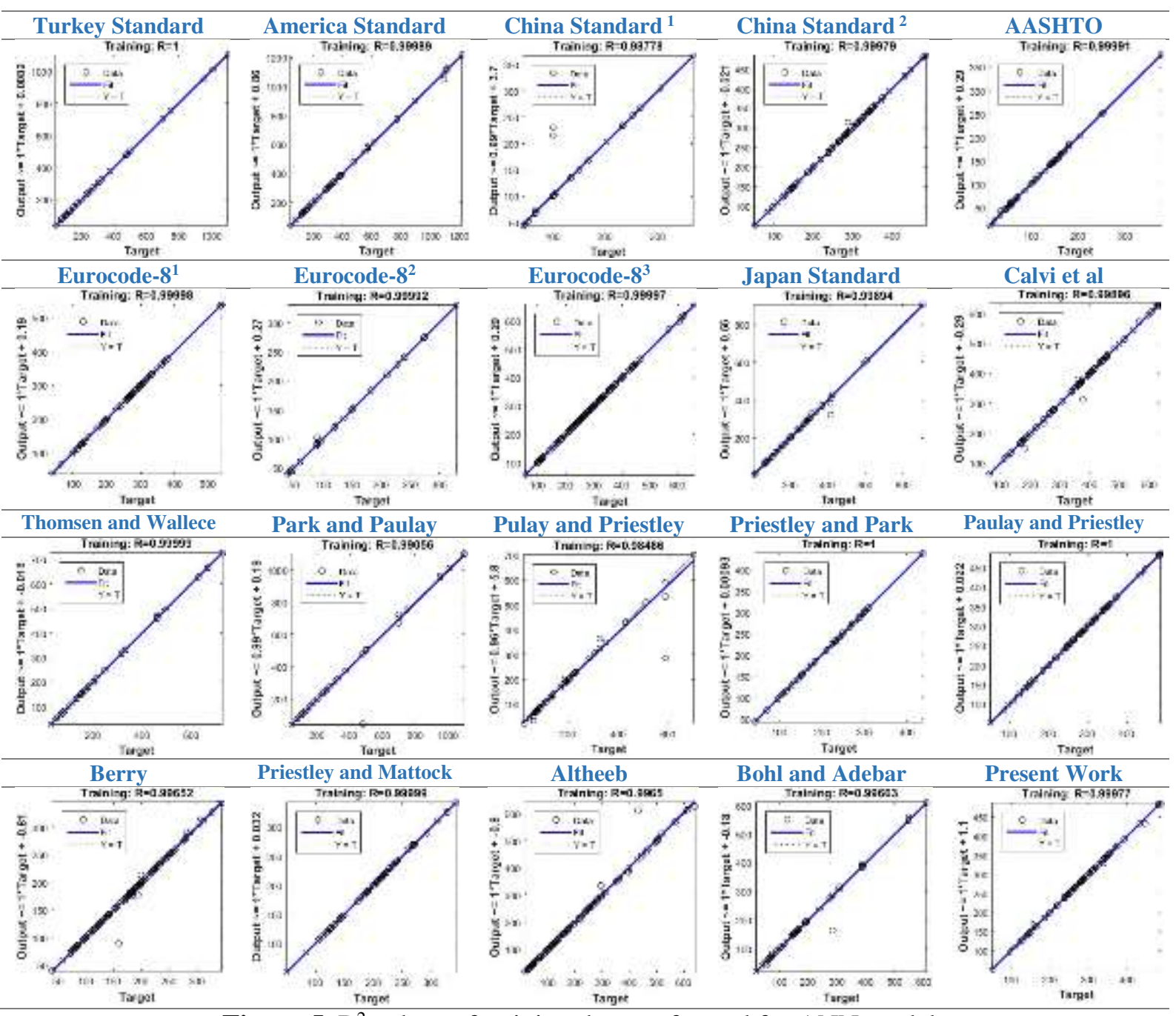

Figure 5. $\mathrm{R}^{2}$ values of training data performed for ANN models

As shown at the Figure 6, $\mathrm{R}^{2}$ values of the test data vary between 0.99 and 1.00 . This situation is an indicator suggesting the ANN model is installed quite successfully. Developed ANN model is able to use ten different input parameters to determine plastic hinge lengths of the columns and/or the shear walls quite accurately. 


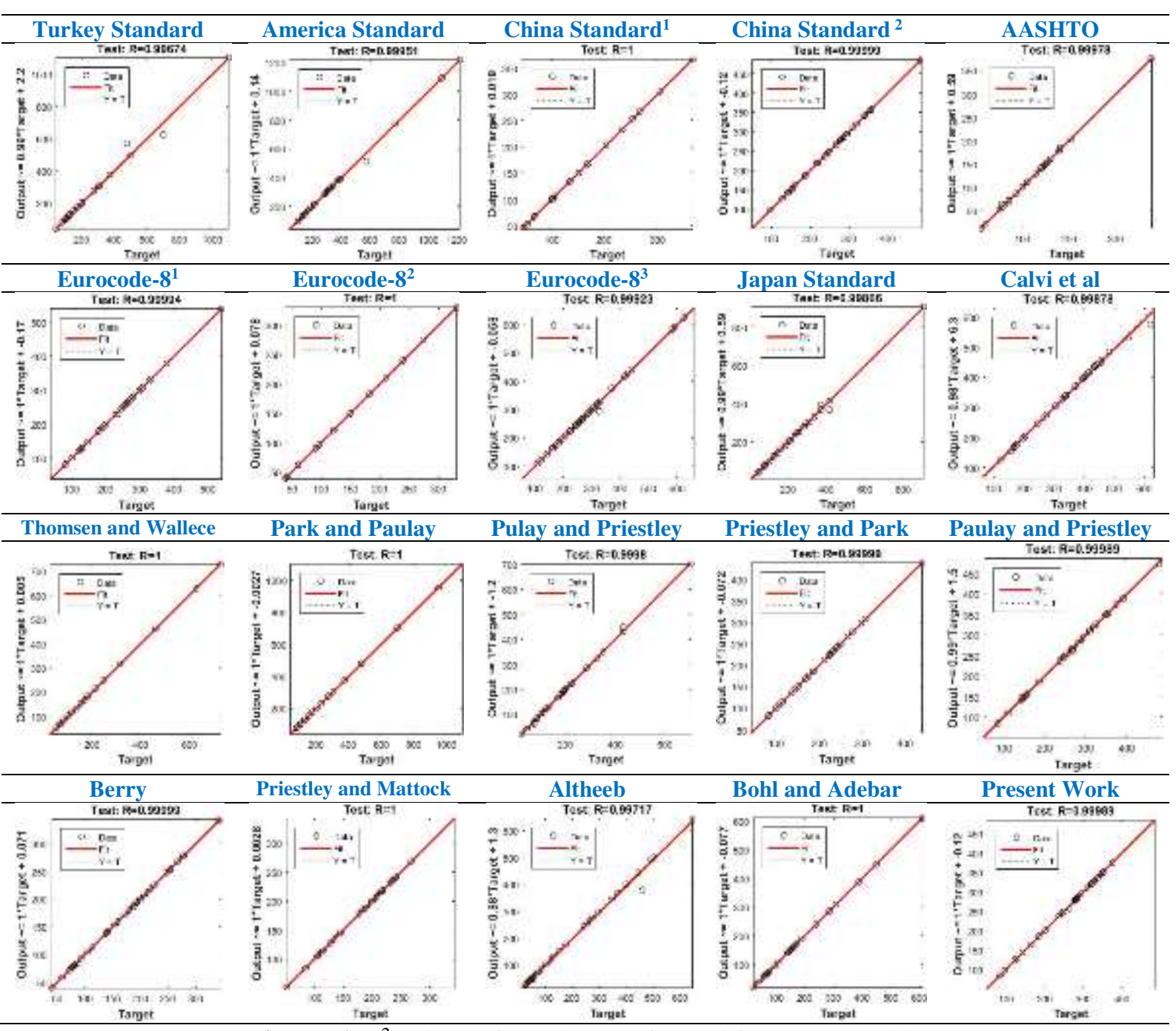

Figure 6. $\mathrm{R}^{2}$ values of test data performed for ANN models

The RMSE (root-mean-square error) and MAPE (mean absolute percentage error) performance data sets of ANN model is presented at Table 7. Following equations are used to determine the RMSE and MAPE values.

$$
\begin{aligned}
\text { RMSE } & =\sqrt{\frac{1}{p} \sum\left|t_{i}-o_{i}\right|^{2}} \\
\text { MAPE } & =\left|\left(\frac{t_{i}-o_{i}}{o_{i}}\right)\right| x 100
\end{aligned}
$$


Table 7. ANN's performance data

\begin{tabular}{|c|c|c|c|c|c|}
\hline \multirow[t]{2}{*}{ References } & \multicolumn{2}{|c|}{ Training Set } & \multicolumn{2}{|c|}{ Testing Set } & \multirow[t]{2}{*}{ Termination epoch } \\
\hline & RMSE & MAPE & RMSE & MAPE & \\
\hline Turkey Standard (2019) & 1.274 & 0.751 & 3.912 & 0.092 & 96 \\
\hline America Standard ( 2019) & 1.933 & 0.363 & 1.943 & 0.007 & 47 \\
\hline China Standard $^{1}(2008)$ & 1.811 & 0.966 & 0.075 & 0.014 & 61 \\
\hline China Standard $^{2}$ (2008) & 0.368 & 0.143 & 0.144 & 0.004 & 14 \\
\hline AASHTO (2002) & 0.193 & 0.012 & 0.563 & 0.224 & 8 \\
\hline Eurocode-8 ${ }^{1}$ (2005) & 0.341 & 0.149 & 0.290 & 0.003 & 9 \\
\hline Eurocode-8 ${ }^{2}$ (2005) & 0.232 & 0.181 & 0.137 & 0.019 & 15 \\
\hline Eurocode-8 ${ }^{3}(2005)$ & 0.534 & 0.023 & 0.122 & 0.009 & 51 \\
\hline Japan Standard (1996) & 0.450 & 0.125 & 0.467 & 0.132 & 11 \\
\hline Thomsen and Wallece (2004) & 0.744 & 0.202 & 0.322 & 0.230 & 29 \\
\hline Park and Paulay (1990) & 1.430 & 0.452 & 1.021 & 0.302 & 14 \\
\hline Pulay and Priestley (1992) & 0.230 & 0.067 & 0.432 & 0.006 & 20 \\
\hline Priestley and Park (1987) & 0.143 & 0.184 & 0.558 & 0.018 & 9 \\
\hline Paulay and Priestley (1992) & 0.394 & 0.010 & 0.126 & 0.221 & 32 \\
\hline Berry (2008) & 0.666 & 0.191 & 0.852 & 0.630 & 7 \\
\hline Priestley and Mattock (2019) & 0.204 & 0.099 & 1.122 & 0.145 & 39 \\
\hline Altheeb et al. (2015) & 1.021 & 0.761 & 0.673 & 0.026 & 19 \\
\hline Bohl and Adebar (2011) & 0.332 & 0.150 & 0.247 & 0.562 & 6 \\
\hline Calvi et al (2007) & 0.351 & 0.338 & 0.695 & 0.068 & 33 \\
\hline Proposed Formula & 0.291 & 0.094 & 0.312 & 0.101 & 14 \\
\hline
\end{tabular}

Both ANN models and some multiple regression-based formulas have been suggested, together. The presented formulas are obtained by using input parameters included within the ANN models. The suggested formulas under the scope of this study are given at Table 8.

Table 8. Multiple regression based suggested formulas

\begin{tabular}{llr}
\hline \multicolumn{1}{c}{ Ref. } & \multicolumn{1}{c}{ Formula } & $\mathbf{R}^{2}$ \\
\hline Proposed formula & $0,07 \mathrm{H}-0,01 \mathrm{~L}+0,08 \mathrm{t}-0,21 \mathrm{f}_{\mathrm{c}}+0.18 \mathrm{f}_{\mathrm{y}}+0,1 \mathrm{f}_{\mathrm{u}}+6,4 \rho-0,03 \mathrm{~V}+(\mathrm{M} / 50000)+6,6 \mathrm{~d}-$ & - \\
& 100 & \\
\hline $\begin{array}{l}\text { Turkey Standard } \\
\text { (2019) }\end{array}$ & $5,5\left(30+0,03 \mathrm{H}+0,25 \mathrm{~L}-0,15 \mathrm{t}-0,09 \mathrm{f}_{\mathrm{c}}+0,09 \mathrm{f}_{\mathrm{y}}-0,06 \mathrm{f}_{\mathrm{u}}-0,73 \rho-0,03 \mathrm{~V}-0,91 \mathrm{~d}\right)^{0,8}$ & 0.97 \\
\hline $\begin{array}{l}\text { America Standard } \\
\text { (“ACI CODE-318-19: }\end{array}$ & $\left(200+0,05 \mathrm{H}+0,38 \mathrm{~L}-0,23 \mathrm{t}-0,14 \mathrm{f}_{\mathrm{c}}+0,14 \mathrm{f}_{\mathrm{y}}-0,1 \mathrm{f}_{\mathrm{u}}-1,1 \rho-0,06 \mathrm{~V}-1,4 \mathrm{~d}\right)$ & 0.94 \\
2019) & & \\
\hline AASHTO (2002) & $\left(0,1 \mathrm{H}-0,01 \mathrm{~L}+0,03 \mathrm{t}-0,05 \mathrm{f}_{\mathrm{c}}+0,26 \mathrm{f}_{\mathrm{y}}+0,01 \mathrm{f}_{\mathrm{u}}+1,6 \rho-0,02 \mathrm{~V}+5,7 \mathrm{~d}-104\right)^{0,9}$ & 0.74 \\
\hline China Standard (2008) & $-0,07 \mathrm{H}-0,02 \mathrm{~L}+0,04 \mathrm{t}-0,07 \mathrm{f}_{\mathrm{c}}+0,38 \mathrm{f}_{\mathrm{y}}+0,01 \mathrm{f}_{\mathrm{u}}+2,3 \rho-0,02 \mathrm{~V}+\mathrm{M}^{0,3}+8,3 \mathrm{~d}-150$ & 0.98 \\
\hline Eurocode-8 (2005) & $0,1 \mathrm{H}-0,01 \mathrm{~L}+0,03 \mathrm{t}-0,05 \mathrm{f}_{\mathrm{c}}+0,26 \mathrm{f}_{\mathrm{y}}+0,01 \mathrm{f}_{\mathrm{u}}+1,6 \rho-0,02 \mathrm{~V}+\mathrm{M}^{0,3}+5,7 \mathrm{~d}-125$ & 0.96 \\
\hline Japan Standard (1996) & $0,04\left(0,1 \mathrm{H}-0,01 \mathrm{~L}+0,03 \mathrm{t}-0,05 \mathrm{f}_{\mathrm{c}}+0,26 \mathrm{f}_{\mathrm{y}}+0,01 \mathrm{f}_{\mathrm{u}}+1,6 \rho-0,02 \mathrm{~V}+\mathrm{M}^{0,2}+5,7 \mathrm{~d}-\right.$ & 0.71 \\
\hline & $100)^{1,6}$ & \\
\hline
\end{tabular}




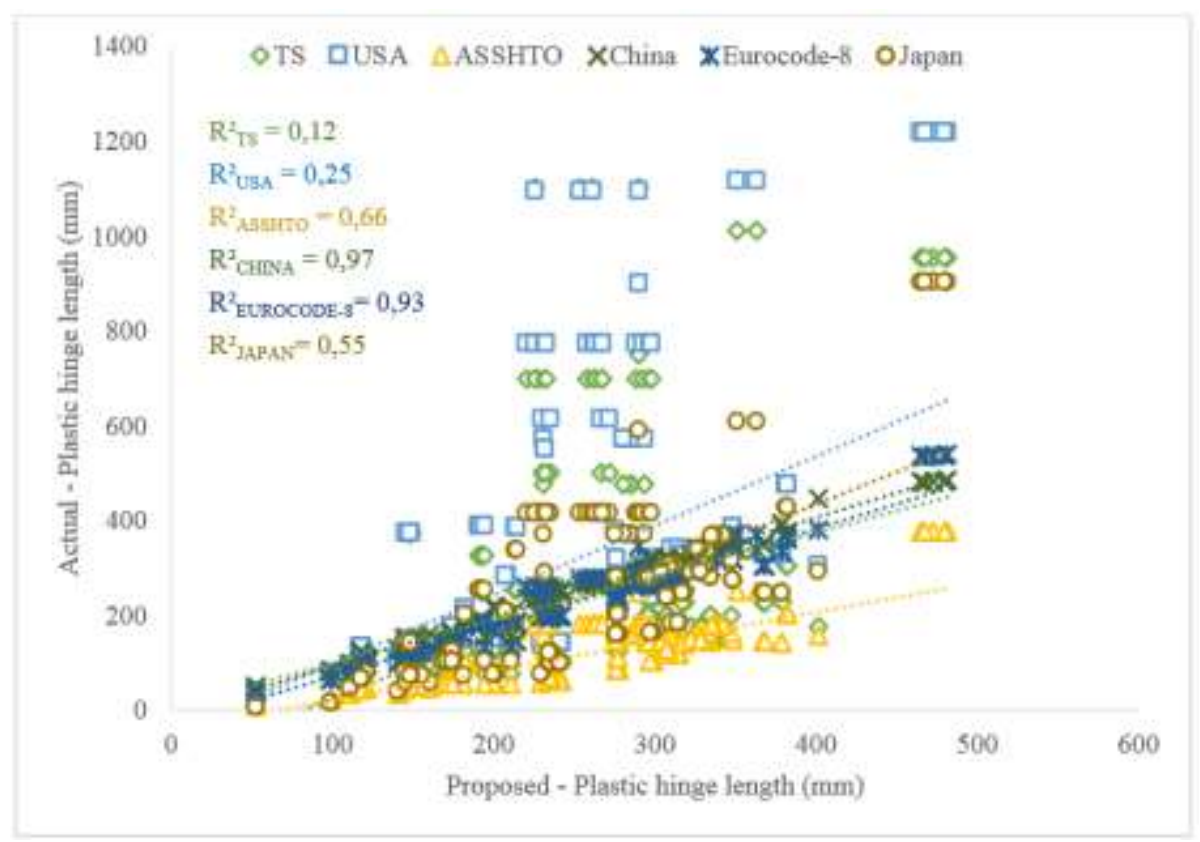

Figure 7. Relationship of the formula for plastic hinge length with related international standards

As presented at Figure 7, the suggested formula within the scope of this study is able to determine the plastic hinge length more accurately than that of Eurocode- 8 and China regulations. However, the accuracy of the suggested formula is relatively low for the countries such as Turkey and US, which is considered as a result of regional construction quality related variations.

The comparison between actual values and plastic hinge lengths calculated using the formulas are provided at Table 8 . It has been understood that, the $\mathrm{R}^{2}$ values of formulas provided for TS, USA, China, and Eurocode- 8 are relatively high $(>0.95)$. The plastic hinge lengths calculated using the formulas suggested in this study are to be almost the same as lengths calculated using the formulas indicated in respective regulations. Nonetheless, the correlation between plastic hinge length calculations obtained using the formulas suggested in this study and using formulas included in AASHTO and Japanese regulations is relatively low. The above-mentioned variation is visualized through the Figure 8 . Especially, the gap area between evaluated and predicted plastic hinge lengths throughout the Figure 8, implies the regional construction parameters affect, which is also indicates varying worldwide research parameters and laboratory conditions etc. However, the ANN gathers to evaluate plastic hinge length in an innovative envision, because of inevitable affecting parameter differences, which are not controllable, the plastic hinge length cannot be determined exactly, but not more accurate than ANN models. 


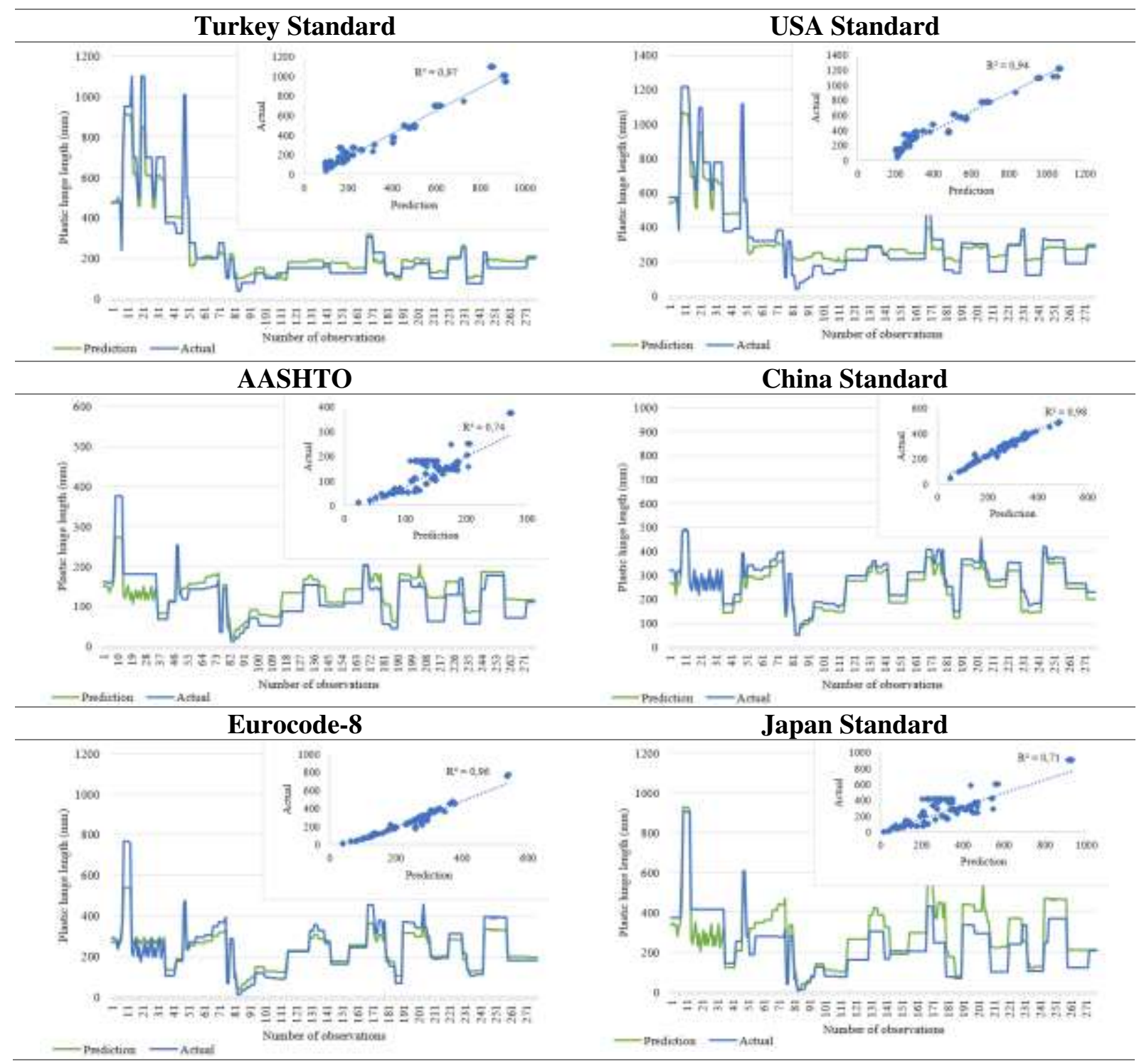

Figure 8. Comparison of plastic hinge lengths (Actual-Estimated values)

\section{CONCLUSION}

The purpose of this study is to evaluate the effect of plastic hinge zone on the behavior of the RC columns and shear walls and also to make a comparison between numerical or numerically supported data at the literature, including the plastic hinge formulas. This study is also aimed to present an ANN based numerical plastic hinge formula for columns and shear walls. As a result of this study, the following results were obtained:

I. In this study, it was determined that the plastic hinge lengths of columns and shear walls can be estimated with ANN. The ANN model has been tested on 19 different approaches (for plastic hinge length). The minimum $\mathrm{R}^{2}$ value obtained in the test data of all approaches is 0.99 .

II. According to the present work, some formulas based on multiple regression have been suggested, also. The proposed formulas have been proposed essentially for relevant standards, which are consist of input data included within the ANN model. In this context, six different formulas have been proposed, where the $\mathrm{R}^{2}$ values of the formulas are between 0.71 and 0.97 .

III. It has been determined that the ANN model has higher predictive power than multiple regression-based formulas. Therefore, using ANN based on the L-M algorithm provides a great 
advantage in predicting the plastic hinge length. However, the ANN gathers to evaluate plastic hinge length in an innovative envision, because of inevitable affecting parameter differences, which are not controllable, the plastic hinge length cannot be determined exactly, but not more accurate than ANN models.

IV. No formulas were encountered in the literature about plastic hinge lengths of RC floors. This is mainly due to the fact that floors are built in accordance with construction rules for RC beams and similar structural members. Generally, reinforcement calculations are evaluated for onemeter length and distributed evenly to the floor. Hence, the plastic hinge observations for the beams are also considered valid for floors. As a result, the plastic hinge length is half the length of beam height $(\mathrm{h} / 2)$ for $\mathrm{RC}$ beams is applicable also for floors. However, due to the fact that floor thickness is relatively small, it is apparent that $\mathrm{h} / 2$ will correlate to a very small area. For this reason, there are no special reinforcement specifications for RC floors, as it is the case for beams.

\section{Nomenclature}

L : : Height of column/shear wall

b : Short side in rectangular section elements or diameter in circular sections

$d_{s} \quad$ : Longitudinal reinforcement diameter

$\mathrm{f}_{\mathrm{y}} \quad$ : Yield strength of longitudinal reinforcement

$\mathrm{f}_{\mathrm{u}} \quad$ : Ultimate strength of longitudinal reinforcement

$\mathrm{H} \quad$ : Section width in the direction of loading or cross section diameter in circular columns

z : Shear span

d : Effective height

$\mathrm{f}_{\mathrm{c}} \quad$ : Compressive concrete strength

$\mathrm{A}_{\mathrm{s}} \quad$ : Reinforcement area

Ag : Cross section

$\mathrm{h} \quad$ : Section height

P : : Axial load

M : Moment

$\mathrm{V}$ : Shear force

t : Thickness of shear wall

$\rho \quad$ : Reinforcement ratio

\section{DATA AVAILABILITY}

Some or all data, models or code that support the findings of this study are available from the corresponding author upon reasonable request.

\section{REFERENCES}

1. Hwang, H.-J. and H.-G. Park, Plastic Hinge Model for Performance-Based Design of BeamColumn Joints. Journal of Structural Engineering, 2021. 147(2): p. 04020336.

2. Feng, D.-C., et al., Data-Driven Approach to Predict the Plastic Hinge Length of Reinforced Concrete Columns and Its Application. Journal of Structural Engineering, 2021. 147(2): p. 04020332.

3. Ren, L., et al., Numerical Investigation on Plastic Hinge Length of Ultra-high Performance Concrete Column under Cyclic Load. Journal of Earthquake Engineering, 2020: p. 1-19.

4. Aydin, A.C., et al., CFRP Effect on the Buckling Behavior of Dented Cylindrical Shells. International Journal of Steel Structures, 2020. 20(2): p. 425-435. 
5. Hoult, R.D., H.M. Goldsworthy, and E. Lumantarna, Plastic hinge length for lightly reinforced C-shaped concrete walls. Journal of Earthquake Engineering, 2020. 24(7): p. 1083-1114.

6. Álvarez, R., J.I. Restrepo, and M. Panagiotou, RC wall plastic hinge out-of-plane buckling: Analysis using the nonlinear beam-truss model. Journal of Structural Engineering, 2020. 146(12): p. 04020274.

7. Aydın, A.C., and Barış Bayrak, Evaluation of $R C$ shear walls in terms of different building materials. Niğde Ömer Halisdemir Üniversitesi Mühendislik Bilimleri Dergisi 2020. 10: p. 217240.

8. B02-01-, J.T., Guidelines for seismic design of highway bridges. China: Department of Transportation, 2008.

9. Ning, C.-L. and B. Li, Probabilistic approach for estimating plastic hinge length of reinforced concrete columns. Journal of Structural Engineering, 2016. 142(3): p. 04015164.

10. Yuan, F. and Y.-F. Wu, Effect of load cycling on plastic hinge length in RC columns. Engineering Structures, 2017. 147: p. 90-102.

11. Mahyar MAALI, M.K., Abdulkadir Cüneyt AYDIN,Bariş BAYRAK,Haluk Gorkem ALCAN, Shear Wall Design within the Light of Prominent Standards. Civil Engineering Beyond Limits., 2020. 1.

12. Officials, T., Standard specifications for highway bridges. 2002: AASHTO.

13. Standard, B., Eurocode 8: Design of structures for earthquake resistance. Part, 2005. 1: p. 1998-1.

14. Lu, J., et al., Experimental and numerical investigation of the seismic performance of railway piers with increasing longitudinal steel in plastic hinge area. Earthquakes and Structures, 2019. 17(6): p. 545-556.

15. Baker, A.L.L., The ultimate-load theory applied to the design of reinforced \& prestressed concrete frames. 1956: Concrete Publications.

16. Priestley, M. and R. Park, Strength and ductility of concrete bridge columns under seismic loading. Structural Journal, 1987. 84(1): p. 61-76.

17. Paulay, T. and M.N. Priestley, Seismic design of reinforced concrete and masonry buildings. 1992.

18. Bae, S. and O. Bayrak, Plastic hinge length of reinforced concrete columns. ACI Structural Journal, 2008. 105(3): p. 290.

19. Berry, M.P., D.E. Lehman, and L.N. Lowes, Lumped-plasticity models for performance simulation of bridge columns. ACI Structural Journal, 2008. 105(3): p. 270.

20. Türkiye Bina Deprem Yönetmeliği (TBDY-2018), A.v.A.D.Y. Başkanlığı, Editor. 2018.

21. ACl Committee 318. Building code requirements for structural concrete (ACl 318-19); and commentary (ACl 318R-19). 2019.

22. Altheeb, A., et al. Analytical modelling of strain penetration deformation in reinforced concrete members. in Proceedings of the 10th Pacific Conference on Earthquake Engineering, Sydney, Australia. 2015.

23. Bohl, A. and P. Adebar, Plastic hinge lengths in high-rise concrete shear walls. ACl Structural Journal, 2011. 108(2): p. 148.

24. Calvi, G., M. Priestley, and M. Kowalsky. Displacement based seismic design of structures. in New Zealand Conference on Earthquake Engineering. 2007. Citeseer.

25. Thomsen IV, J.H. and J.W. Wallace, Displacement-based design of slender reinforced concrete structural walls-experimental verification. Journal of structural engineering, 2004. 130(4): p. 618-630.

26. FOROUGHI, S. and S.B. YÜKSEL, Investigation of Displacement Behavior of Reinforced Concrete Shear Walls with Different Plastic Hinge Relationships. Uluslararası Doğu Anadolu Fen Mühendislik ve Tasarım Dergisi, 2019. 1(2): p. 196-211.

27. Park, R. and T. Paulay, Strength and ductility of concrete substructures of bridges. RRU Bulletin, 1990. 84. 
28. Aydin, A.C. and B. Bayrak, The torsional behavior of reinforced self-compacting concrete beams. Advances in concrete construction, 2019. 8(3): p. 187-198.

29. Hasar, U.C., et al., Water-to-cement ratio prediction using ANNs from non-destructive and contactless microwave measurements. Progress In Electromagnetics Research, 2009. 94: p. 311-325.

30. Al Shamisi, M.H., A.H. Assi, and H.A. Hejase, Using MATLAB to develop artificial neural network models for predicting global solar radiation in Al Ain City-UAE, in Engineering education and research using MATLAB. 2011, Citeseer.

31. Gavin, H.P., The Levenberg-Marquardt algorithm for nonlinear least squares curve-fitting problems. Department of Civil and Environmental Engineering, Duke University, 2019: p. 119.

32. Marquardt, D.W., An algorithm for least-squares estimation of nonlinear parameters. Journal of the society for Industrial and Applied Mathematics, 1963. 11(2): p. 431-441.

33. Svozil, D., V. Kvasnicka, and J. Pospichal, Introduction to multi-layer feed-forward neural networks. Chemometrics and intelligent laboratory systems, 1997. 39(1): p. 43-62.

34. Chen, T.-c., et al. , Acceleration of Levenberg-Marquardt training of neural networks with variable decay rate. Proceedings of the International Joint Conference on Neural Networks, 2003. 3.

35. Barda, F., J. Hanson, and W. Corley, Shear Strength of Low-Rise Walls with Boundary Elements. Reinforced Concrete in Seismic Zones. 1977, American Concrete Institute, Farmington Hills, MI, USA, ACI SP-53-8.

36. Synge, A.J., Ductility of squat shear walls. 1980: University of Canterbury Library.

37. Oesterle, R., et al., Earthquake resistant structural walls-tests of isolated walls. Research and Development Construction Technology Laboratories, Portland Cement Association, 1976.

38. Sato, S., et al., Behavior of Shear Wall Using Various Yield Strength of Rebar Part 1: An Experimental Study. 1989.

39. Lefas, I.D., M.D. Kotsovos, and N.N. Ambraseys, Behavior of reinforced concrete structural walls: strength, deformation characteristics, and failure mechanism. Structural Journal, 1990. 87(1): p. 23-31.

40. Palermo, D., F.J. Vecchio, and H. Solanki, Behavior of three-dimensional reinforced concrete shear walls. ACl Structural Journal, 2002. 99(1): p. 81-89.

41. Ma, J. and B. Li, Experimental and Analytical Studies on H-Shaped Reinforced Concrete Squat Walls. ACI Structural Journal, 2018. 115(2).

42. Gill, W.D., Ductility of rectangular reinforced concrete columns with axial load. 1979.

43. Soesianawati, M., Limited ductility design of reinforced concrete columns. 1986.

44. Zahn, F.A., Design of reinforced concrete bridge columns for strength and ductility. 1985.

45. Watson, S., Design of reinforced concrete frames of limited ductility. 1989.

46. Tanaka, H., Effect of lateral confining reinforcement on the ductile behaviour of reinforced concrete columns. 1990.

47. Nagasaka, T., Effectiveness of steel fiber as web reinforcement in reinforced concrete columns. Transactions of the Japan Concrete Institute, 1982. 4(1): p. 493-500.

48. Ohno, T. and T. Nishioka, An experimental study on energy absorption capacity of columns in reinforced concrete structures. Doboku Gakkai Ronbunshu, 1984. 1984(350): p. 23-33.

49. Ohue, M., et al., The behavior of RC short columns failing in splitting bond-shear under dynamic lateral loading. Transactions of the Japan Concrete Institute, 1985. 7(1): p. 293-300.

50. Kanda, M., Analytical study on elasto-plastic hysteretic behavior of reinforced concrete members. Transaction of the Japan Concrete Institute, 1988. 10: p. 257-264.

51. Muguruma, H., F. Watanabe, and T. Komuro, Applicability of high strength concrete to reinforced concrete ductile column. Transactions of the Japan Concrete Institute, 1989. 11(1): p. 309-316.

52. Sakai, Y., et al., Experimental studies on flexural behavior of reinforced concrete columns using high-strength concrete. 1990: Japan Concrete Institute Sapporo. 
53. Wight, J.K.S., M.A., Shear Strength Decay in Reinforced Concrete Columns Subjected to Large Deflection Reversals. 1973-08: University of Illinois Engineering Experiment Station. College of Engineering. University of Illinois at Urbana-Champaign.

54. Atalay, M.B. and J. Penzien, The seismic behavior of critical regions of reinforced concrete components as influenced by moment, shear and axial force. 1975: Earthquake Engineering Research Center, University of California Berkeley ....

55. Saatcioglu, M. and G. Ozcebe, Response of reinforced concrete columns to simulated seismic loading. Structural Journal, 1989. 86(1): p. 3-12.

56. Galeota, D., M. Giammatteo, and R. Marino. Seismic resistance of high strength concrete columns. in 11th World Conf. on Earthquake Engineering. 1996.

57. Wehbe, N., EERI Annual Student Paper Award Confinement of Rectangular Bridge Columns in Moderate Seismic Areas. Earthquake spectra, 1998. 14(2): p. 397-406.

58. Lynn, A.C., et al., Seismic evaluation of existing reinforced concrete building columns. Earthquake Spectra, 1996. 12(4): p. 715-739.

59. Martirossyan, A. and Y. Xiao, Flexural-shear behavior of high-strength concrete short columns. Earthquake Spectra, 2001. 17(4): p. 679-695.

60. Sugano, S. Seismic behavior of reinforced concrete columns which used ultra-high-strength concrete. in 11th World Conf. on Earthquake Engineering. 1996.

61. Bayrak, O. and S. Sheikh. Confinement steel requirements for high strength concrete columns. in Proceedings of the 11th World Conference on Earthquake Engineering. 1996.

62. Saatcioglu, M. and M. Grira, Confinement of reinforced concrete columns with welded reinforced grids. Structural Journal, 1999. 96(1): p. 29-39.

63. Matamoros, A.B., Study of drift limits for high-strength concrete columns. 1999: University of Illinois at Urbana-Champaign.

64. Mo, Y.-L. and S. Wang, Seismic behavior of RC columns with various tie configurations. Journal of Structural Engineering, 2000. 126(10): p. 1122-1130.

65. Aboutaha, R. and R. Machado, Seismic resistance of steel-tubed high-strength reinforcedconcrete columns. Journal of Structural Engineering, 1999. 125(5): p. 485-494.

66. Thomson, J.H. and J.W. Wallace, Lateral load behavior of reinforced concrete columns constructed using high-strength materials. Structural Journal, 1994. 91(5): p. 605-615.

67. Sezen, H. and J. Moehle. Seismic behavior of shear-critical reinforced concrete building columns. in Seventh US National Conference on Earthquake Engineering, Earthquake Engineering Research Institute, Boston, MA. 2002.

68. Legeron, F. and P. Paultre, Behavior of high-strength concrete columns under cyclic flexure and constant axial load. Structural Journal, 2000. 97(4): p. 591-601.

69. Paultre, P., F. Légeron, and D. Mongeau, Influence of concrete strength and transverse reinforcement yield strength on behavior of high-strength concrete columns. Structural Journal, 2001. 98(4): p. 490-501.

70. Pujol, S., Drift capacity of reinforced concrete columns subjected to displacement reversals. 2002: Purdue University.

71. Takemura, H., Effect of hysteresis on ductility capacity of reinforced concrete bridge piers. Structural Engineering Journal, JSCE, A, 1997. 43: p. 849-848. 